\title{
KALMAN FILTER SEBAGAI METODE ESTIMASI UNTUK MENGUKUR KECEPATAN KENDARAAN
}

\author{
Romi Wiryadinata ${ }^{1}$, Okta Palega $^{2}$

\begin{abstract}
SINKEN Research Group, Jurusan Teknik Elektro, Universitas Sultan Ageng Tirtayasa ${ }^{(1,2)}$
Jl. Jendral Sudirman km.3, Kota Cilegon, Banten, Indonesia

Email :romi@wiryadinata.web.id,oktapalega@gmail.com
\end{abstract}

\begin{abstract}
ABSTRACK
Methods for estimating speed be categorized into two classes, namely active method and passive methods. One method that can be used in speed estimation using a passive method is the Kalman filter. Kalman filter is an very effective estimator that is in estimating state dynamics system involving white noise. In this study, the Kalman filter will be used to estimate the variation of vehicle speed from a speed of 5 $\mathrm{km} / \mathrm{hour}$ to $60 \mathrm{~km} / \mathrm{hour}$. Kalman filter is designed to get input in the form of cascading imagery of the vehicle video recordings. Results of the testing showed that speed can be minimum estimated is $20 \mathrm{~km}$ hour with an error of $4.25 \%$. While the maximum estimated speed is $60 \mathrm{~km} / \mathrm{hour}$ with an error of $0.22 \%$.
\end{abstract}

Keywords: Estimation of speed, Kalman filter, Cascading Image.

\section{PENDAHULUAN}

Berbagai metode untuk estimasi kecepatan diusulkan dalam beberapa tahun terakhir. Semua pendekatan berusaha untuk meningkatkan akurasi dan mengurangi biaya implementasi hardware. Metode estimasi kecepatan dikategorikan menjadi dua kelas. Pertama, metode aktif: metode yang paling populer termasuk menggunakan perangkat RADAR dan LIDAR untuk mendeteksi kecepatan kendaraan. Kedua, metode pasif: Dalam metode ini, informasi kecepatan diambil dari urutan gambar real - time lalu lintas, yang diambil dari kamera pasif. Metode aktif biasanya lebih mahal dibandingkan dengan metode pasif ( $\mathrm{Rad}$, G.A.R \& Mohamadi, 2007).

Kalman filter adalah salah satu metode yang dapat diterapkan pada metode pasif. Kalman filter merupakan estimator yang sangat efektif dalam mengestimasi state dinamika sistem yang melibatkan white noise. Kalman filter dapat menghilangkan noise dari suatu sinyal yang mengandung informasi dan mengambil informasi tersebut untuk diproses lebih lanjut (Kasiyanto, I., 2008).
Kalman filter umumnya digunakan untuk meghapus noise tidak hanya pada sistem yang linier dengan meminimalkan nilai kovarian error estimasinya (Kleinbauer, R, 2004). Kalman filter adalah sebuah alat yang dapat mengestimasi varibel dari suatu proses yang besar (Simon, D, 2001 \& Kleinbauer, R, 2004). Kalman filter tidak hanya bekerja dengan baik pada prakteknya, namun secara teori menarik karena dapat menunjukan kemungkinan seluruh filter. Berdasarkan hal tersebut, Kalman filter dipilih sebagai metode dalam mengestimasi kecepatan dalam penelitian ini.

Pada penelitian ini dibuat simulasi sistem pengestimasi kecepatan dengan algoritma dari fase kerja Kalman filter yang memanfaatkan umpan balik untuk memprediksi dan mengkoreksi sistem keadaan dalam bentuk program menggunakan MATLAB. Sistem pengestimasi kecepatan diuji dengan dengan berbagai variasi nilai kecepatan. Variasi kecepatan yang dipilih adalah $5 \mathrm{~km} / \mathrm{jam}, 10$ $\mathrm{km} / \mathrm{jam}, 20 \mathrm{~km} / \mathrm{jam}, 30 \mathrm{~km} / \mathrm{jam}, 40 \mathrm{~km} / \mathrm{jam}$, $50 \mathrm{~km} / \mathrm{jam}$ dan $60 \mathrm{~km} / \mathrm{jam}$. Variasi nilai kecepatan ini disesuaikan dengan PP No. 73 Tahun 2013 tentang batas kecepatan (Republik Indonesia, 2013) 
Pada bab tiga ruang lalu lintas bagian kedua batas kecepatan disebutkan bahwa kecepatan maksimal untuk kawasan perkotaan adalah $50 \mathrm{~km} / \mathrm{jam}$. Dengan toleransi yang diberikan adalah sebesar $10 \mathrm{~km} / \mathrm{jam}$. Sehingga kecepatan maksimal yang ditentukan adalah $60 \mathrm{~km} / \mathrm{jam}$.

Data input yang dipergunakan dalam penelitian adalah runtun citra. Video rekaman kendaraan direkam menggunakan kamera yang disanggah menggunakan tripod. Hasil video rekaman kemudian disimpan pada media penyimpanan dengan format *avi. Runtun citra yang menjadi data input dihasilkan dari splitting video rekaman kendaraan tersebut dan disimpan dengan format *.PNG.

Tujuan dari penelitian ini adalah untuk mengetahui hasil dari estimasi kecepatan kendaraan menggunakan Kalman filter. Selain itu, tujuan penelitian adalah mengetahui batas kecepatan minimal dan maksimal yang dapat terestimasi.

\section{METODOLOGI PENELITIAN}

\subsection{Kalman Filter}

Kalman filter dalam penelitian ini dipergunakan sebagai metode dalam estimasi kecepatan. Metode Kalman filter merupakan suatu metode yang dapat dipergunakan untuk mengestimasi variabel state dari sistem dinamik stokastik linier yang terkorupsi oleh whitenoise. State dari suatu sistem dapat diestimasi oleh Kalman filter dengan memodelkan sistem tersebut terlebih dahulu.

\subsubsection{State Vektor}

State vektor merupakan penggambaran dari suatu sistem dinamik dan mewakilkan derajat kebebasan (degrees of freedom) dari suatu benda. Elemen variabel dari state vektor dapat bermacam - macam isinya, seperti posisi, kecepatan, akselerasi dan lainnya. Contoh yang sangat sederhana adalah sebuah kereta yang melaju dengan kecepatan konstan pada jalan yang lurus. Pada kasus ini, kereta memiliki 2 derajat kebebasan, yaitu jarak (s) dan kecepatan (v) (Kleinbauer, R, 2004).

$$
X=\left[\begin{array}{l}
s \\
v
\end{array}\right]
$$

Obyek dalam penelitian merupakan sebuah sepeda motor. Pada hal ini, motor memiliki kesamaan dengan kereta yaitu tergolong dalam sistem linier. Hal ini dapat dilihat dari derajat kebebasan yang sama. Kereta memiliki derajat kebebasan posisi dan kecepatan, begitu pula dengan motor. State vektor yang dirancang dalam penelitian berjumlah empat state yaitu posisi $\mathrm{x}$, posisi $\mathrm{y}$, kecepatan $\mathrm{x}$ dan kecepatan $\mathrm{y}$.

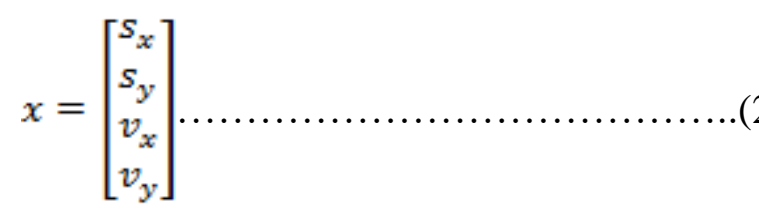

\subsubsection{Algoritma Kalman Filter}

Algoritma pada Kalman filter merupakan suatu fase kerja pengolahan state vektor. Fase kerja ini terdiri dari dua langkah, yaitu:

1. Prediksi

2. Koreksi

Kedua fase kerja ini melakukan perhitungan berulang (looping) hingga batas waktu yang ditentukan. Pada tiap fase kerja terdapat rumus perhitungan sendiri untuk mengestimasi state vektor. Fase kerja dari Kalman filter dapat dilihat pada gambar 1.

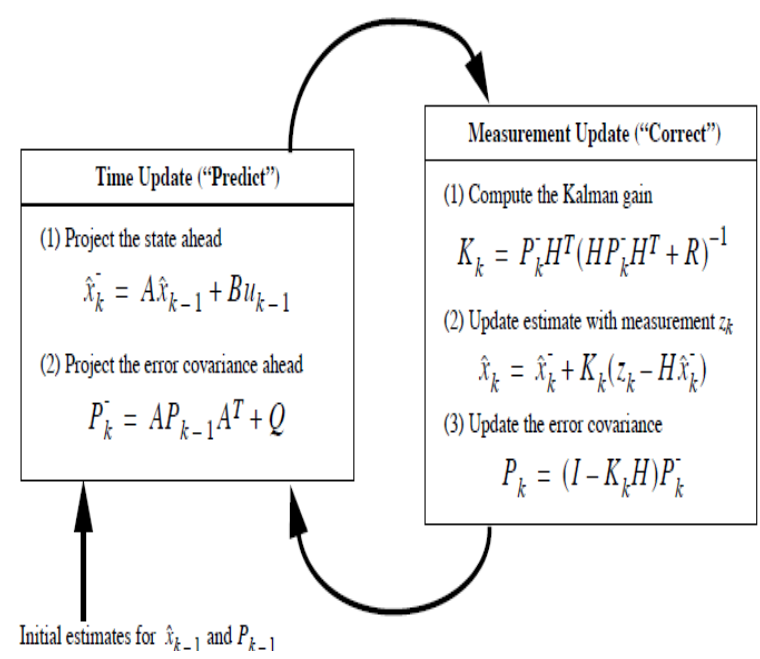

Gambar 1. Fase Kerja Kalman Filter. 
1. Fase Prediksi

Fase prediksi dari Kalman filter dinyatakan dengan persamaan:

State Prediksi:

$\hat{X}_{k+1}=A_{k} \hat{X}_{k}+B_{k} U_{k}$

Kovarian estimate prediksi:

$P_{k+1}=A_{k} P_{k} A_{k}^{T}+Q_{k}$

\section{Fase Koreksi}

Fase koreksi ditunjukkan oleh persamaan:

Kovarian pengukuran:

$S_{k}=H_{k} P_{k} H_{k}^{T}+R_{k}$

Penguatan Kalman:

$K_{k}=P_{k} H_{k}^{T} S_{k}^{-1}$

Estimate state update:

$\hat{X}_{k+1}=\hat{X}_{k}+K_{k} \tilde{y}_{k}$

Kovarian estimate update:

$P_{k+1}=\left(I-K_{k} H_{k}\right) P_{k}$

dengan $\hat{X}_{k}$ adalah state vektor, $U_{k}$ merupakan masukan kontrol dan $A_{k}, B_{k}, H_{k}$ masing masing adalah matrik transisi dari vektor yang terkait dengannya; $Q_{k}$ dan $R_{k}$ masing masing adalah derau proses dan derau pengukuran.

Pada penelitian ini, nilai derau $\operatorname{proses}\left(Q_{k}\right)$ ditentukan sesuai dengan jumlah state pada state vektor, yaitu sebanyak empat state. State posisi memiliki nilai $\frac{d t^{2}}{2}$ sedangkan state kecepatan memiliki nilai $d_{t}$. Keempat state dikalikan untuk mendapatkan nilai $Q_{k}$. Nilai $Q_{k}$ yang sudah didapatkan kemudian dikalikan dengan nilai noise proses yang berupa noise akselerasi. Noise akselerasi yang diberikan adalah sebesar $1 \mathrm{~m} / \mathrm{dtk}^{2}$. Adapun nilai derau proses yang diberikan pada penelitian dapat dilihat pada persamaan (9).

$$
Q_{k}=\left[\begin{array}{cccc}
\frac{d t^{4}}{4} & 0 & \frac{d t^{3}}{2} & 0 \\
0 & \frac{d t^{4}}{4} & 0 & \frac{d t^{3}}{2} \\
\frac{d t^{3}}{2} & 0 & d t^{2} & 0 \\
0 & \frac{d t^{3}}{2} & 0 & d t 2
\end{array}\right] .
$$

Derau pengukuran $\left(R_{k}\right)$ ditentukan sesuai dengan jumlah state posisi pada state vektor. Sehingga pada penelitian ini terdapat dua nilai $R_{k}$ yaitu derau pengukuran untuk posisi x dan posisi $y$. Besarnya nilai derau pengukuran untuk tiap - tiap posisi adalah sebesar $1 \mathrm{~m}$. Nilai dari derau pengukuran $\left(R_{k}\right)$ dapat dilihat pada persamaan (10).

$$
R_{k}=\left[\begin{array}{cc}
t k n \_x & 0 \\
0 & t k n \_y
\end{array}\right] \text {. }
$$

Nilai $U_{k}$ merupakan nilai percepatan yang diberikan kedalam sistem dan dianggap konstan. Nilai $U_{k}$ yang diinputkan kedalam sistem adalah bernilai $1 \mathrm{~m} / \operatorname{detik}^{2}$. Besarnya masing - masing nilai matrik transisi $A_{k}$, $B_{k}$ dan $H_{k}$ disesuaikan dengan banyaknya jumlah state vektor. Masing - masing nilai matrik transisi tersebut dapat dilihat secara berurutan pada persamaan (11), (12) dan (13).

$A_{k}=\left[\begin{array}{rrrr}1 & 0 & d_{t} & 0 \\ 0 & 1 & 0 & d_{t} \\ 0 & 0 & 1 & 0 \\ 0 & 0 & 0 & 1\end{array}\right]$.

$B_{k}=\left[\begin{array}{c}\frac{d_{t}^{n}}{2} \\ \frac{d_{t}^{n}}{2} \\ d_{t} \\ d_{t}\end{array}\right]$

$H_{k}=\left[\begin{array}{llll}1 & 0 & 0 & 0 \\ 0 & 1 & 0 & 0\end{array}\right]$ 


\section{HASIL DAN PEMBAHASAN}

Pengujian pada program estimasi kecepatan bertujuan untuk mendapatkan nilai kecepatan estimasi terhadap nilai kecepatan aktual pada speedometer. Pengujian program estimasi kecepatan dilakukan dengan cara menguji variasi nilai kecepatan. Variasi nilai kecepatan yang diuji adalah $5 \mathrm{~km} / \mathrm{jam}, 10$ $\mathrm{km} / \mathrm{jam}, 20 \mathrm{~km} / \mathrm{jam}, 30 \mathrm{~km} / \mathrm{jam}, 40 \mathrm{~km} / \mathrm{jam}$, $50 \mathrm{~km} / \mathrm{jam}$ dan $60 \mathrm{~km} / \mathrm{jam}$. Nilai estimasi kecepatan perlu dicari karena nilai tersebut terkandung pada sinyal error. Pencarian nilai estimasi kecepatan dilakukan dengan cara mengkonversikan nilai kecepatan aktual menjadi $\mathrm{m} /$ detik terlebih dahulu, kemudian dicari nilai yang mendekati nilai konversi tersebut.

\section{Pengujian 5 km/jam}

Hasil pengujian kecepatan $5 \mathrm{~km} / \mathrm{jam}$ dapat dilihat pada Gambar 2. Pada Gambar 2 terlihat bahwa saat waktu ke-1 hingga waktu ke-362, kecepatan kendaraan belum dapat terdeteksi. Kecepatan kendaraan baru dapat terdeteksi saat waktu ke-363 hingga ke-470. Hal ini dapat dilihat bahwa pada rentan waktu tersebut, fluktuasi dari grafik menjadi lebih kecil dari rentang waktu sebelumnya. Respon error maksimal yang dihasilkan selama rentang waktu kecepatan kendaraan terdeteksi adalah sebesar 10,25 m/detik dan respon error minimal adalah $3,33 \mathrm{~m} /$ detik.

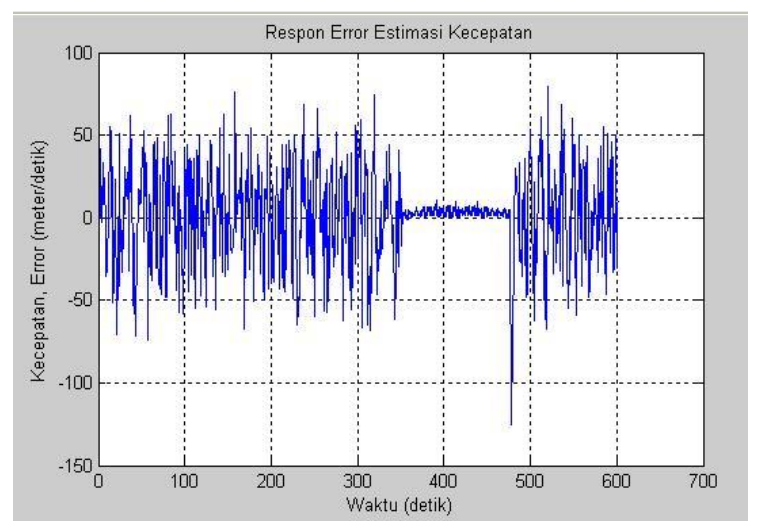

Gambar 2. Respon Error Estimasi Kecepatan $5 \mathrm{~km} / \mathrm{jam}$.
Berdasarkan hasil pengujian tidak ada nilai kecepatan estimasi yang mendekati nilai kecepatan aktualnya, yaitu $5 \mathrm{~km} / \mathrm{jam}$ atau $1,39 \mathrm{~m} /$ detik. Sehingga nilai yang paling mendekati nilai kecepatan aktual adalah nilai dari respon error minimum yaitu 3,33 m/detik atau $11,98 \mathrm{~km} / \mathrm{jam}$. Nilai kecepatan estimasi ini memiliki selisih sebesar $6,98 \mathrm{~km} / \mathrm{jam}$ terhadap kecepatan aktualnya.

\section{Pengujian 10 km/jam}

Hasil dari pengujian estimasi kecepatan 10 $\mathrm{km} / \mathrm{jam}$ dapat dilihat pada grafik Gambar 3.Pada Gambar 3 terlihat saat waktu ke-1 hingga waktu ke-292 detik, nilai respon error terus berfluktuasi hampir mencapai 100 $\mathrm{m} /$ detik. Namun saat waktu ke-293, fluktuasi dari nilai respon error mengecil hingga waktu ke-394. Hal ini menyatakan bahwa kecepatan kendaraan telah terdeteksi. Respon error maksimal yang terjadi selama rentan waktu tersebut adalah $11,07 \mathrm{~m} /$ detik dan respon error minimum adalah $3,28 \mathrm{~m} /$ detik. Saat waktu ke-395 nilai respon error kembali naik hingga waktu ke-526 detik.

Berdasarkan hasil pengujian terlihat bahwa nilai estimasi yang mendekati nilai konversi kecepatan aktual $(2,78 \mathrm{~m} /$ detik $)$ adalah 3,28 $\mathrm{m} /$ detik. Nilai tersebut terdapat pada waktu ke-380. Apabila nilai tersebut dikonversikan menjadi $\mathrm{km} / \mathrm{jam}$ adalah sebesar 11,80 $\mathrm{km} / \mathrm{jam}$. Nilai kecepatan estimasi ini terpaut selisih 1,80 $\mathrm{km} / \mathrm{jam}$ dengan kecepatan aktualnya.

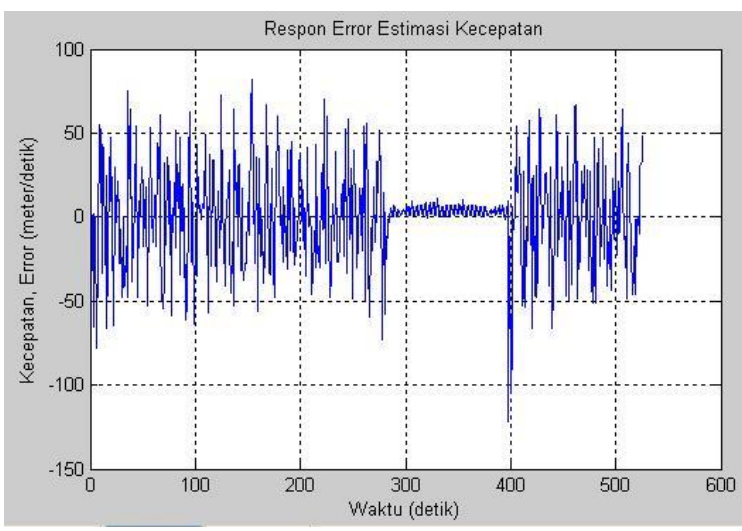

Gambar 3. Respon Error Estimasi Kecepatan $10 \mathrm{~km} / \mathrm{jam}$. 


\section{Pengujian Kecepatan 20 km/jam}

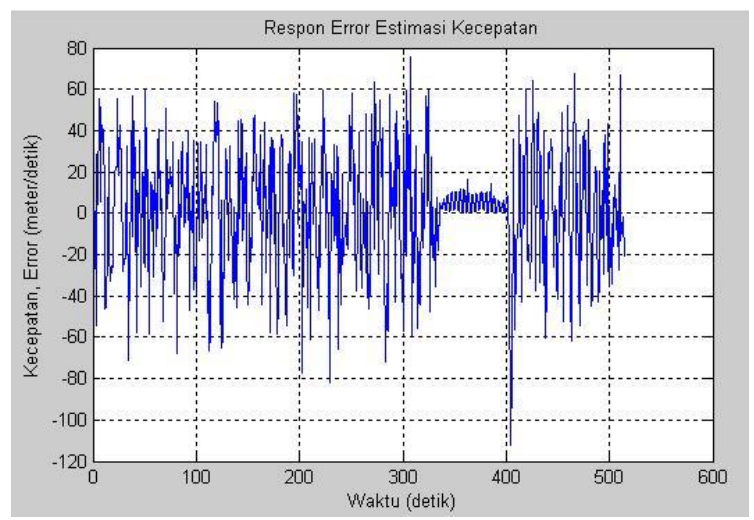

Gambar 4. Respon Error Estimasi Kecepatan $20 \mathrm{~km} / \mathrm{jam}$.

Gambar 4 memperlihatkan hasil pengujian kecepatan 20 km/jam. Pada Gambar 4terlihat bahwa nilai respon error berfluktuasi dari waktu ke-1 hingga ke-338 dengan nilai maksimal hampir mencapai $80 \mathrm{~m} /$ detik. Pada rentan waktu tersebut, kecepatan kendaraan belum terdeteksi. Memasuki waktu ke-339 nilai respon error mengecil hingga waktu ke402 detik. Pada rentan waktu tersebut kecepatan kendaraan mulai terdeteksi. Saat waktu ke-403 nilai respon error membesar kembali hingga waktu ke-514 detik.

Berdasarkan hasil penelitian didapatkan bahwa nilai respon error yang mendekati nilai konversi kecepatan aktual (5,56m/detik) adalah sebesar $5,79 \mathrm{~m} /$ detik. Nilai tersebut terdapat pada waktu ke-394 detik. Apabila nilai kecepatan estimasi tersebut dikonversikan menjadi $\mathrm{km} / \mathrm{jam}$, maka kecepatan bernilai 20,84 $\mathrm{km} / \mathrm{jam}$. Nilai kecepatan estimasi tersebut mempunyai selisih sebesar $0,84 \mathrm{~km} / \mathrm{jam}$ terhadap kecepatan aktualnya.

\section{Pengujian Kecepatan 30 km/jam}

Hasil pengujian keceapatan $30 \mathrm{~km} / \mathrm{jam}$ dapat dilihat pada Gambar 5. Pada Gambar 5 dapat dilihat saat waktu ke-1 detik hingga ke258 detik kecepatan kendaraan belum terdeteksi. Pada rentan waktu tersebut nilai dari respon error hampir mencapai 80 $\mathrm{m} /$ detik. Memasuki waktu ke-259 fluktuasi dari nilai respon error mengecil hingga waktu ke-316. Selama rentan waktu ke-259 hingga waktu ke-316, kecepatan kendaraan telah terdeteksi. Setelah waktu ke-316, kecepatan kendaraan mulai tidak terdeteksi kembali hingga waktu ke-447.

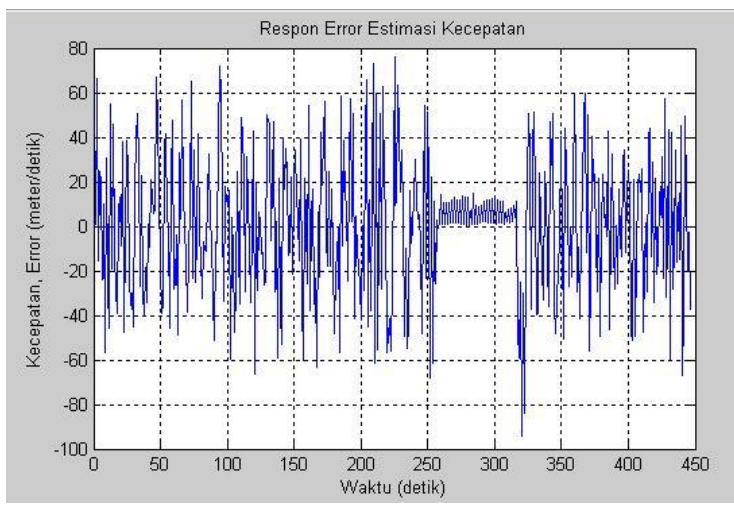

Gambar 5. Respon Error Estimasi Kecepatan $30 \mathrm{~km} / \mathrm{jam}$.

Berdasarkan hasil pengujian yang dilakukan didapatkan bahwa nilai estimasi yang mendekati nilai $8,33 \mathrm{~m} /$ detik adalah nilai $8,43 \mathrm{~m} /$ detik. Nilai kecepatan estimasi tersebut terdapat pada waktu ke-312. Apabila nilai kecepatan estimasi ini dikonversikan kedalam bentuk $\mathrm{km} / \mathrm{jam}$ menjadi 30,35 $\mathrm{km} / \mathrm{jam}$. Nilai kecepatan estimasi ini terpaut selisih $0,35 \mathrm{~km} / \mathrm{jam}$ dengan nilai aktualnya.

\section{Pengujian Kecepatan 40km/jam}

Gambar 6 memperlihatkan hasil pengujian kecepatan $40 \mathrm{~km} / \mathrm{jam}$. Pada Gambar 6 memperlihatkan bahwa nilai dari respon error berfluktuasi cukup tinggi hampir mencapai $100 \mathrm{~m} /$ detik. Hal ini terjadi selama selang waktu ke-1 hingga ke-254 detik. Nilai fluktuasi yang besar ini menunjukan bahwa kecepatan kendaraan belum terdeteksi. Saat waktu ke-255 fluktuasi dari nilai respon error menurun hingga waktu ke-302. Penurunan fluktuasi nilai respon error ini menyatakan bahwa kecepatan kendaraan telah terdeteksi. Memasuki waktu ke-303 hingga ke-398 fluktuasi nilai respon error kembali naik.

Berdasarkan hasil pengujian dapat dilihat bahwa nilai yang paling mendekati nilai konversi kecepatan aktual adalah sebesar $10,82 \mathrm{~m} /$ detik. Nilai tersebut terdapat pada waktu ke-294. Apabila nilai kecepatan estimasi ini di konnversikan kedalam bentuk 
$\mathrm{km} / \mathrm{jam}$ menjadi sebesar 38,95 km/jam. Nilai kecepatan estimasi memiliki selisih sebesar $1,05 \mathrm{~km} / \mathrm{jam}$ terhadap kecepatan aktualnya.

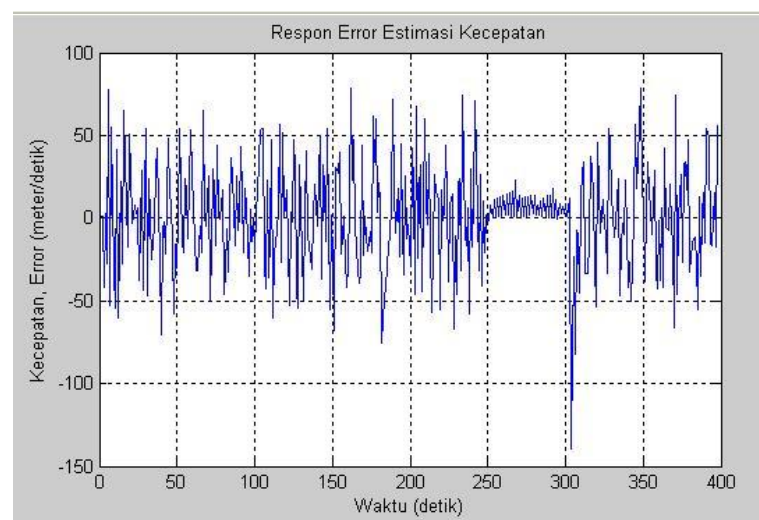

Gambar 6. Respon Error Estimasi Kecepatan $40 \mathrm{~km} / \mathrm{jam}$.

\section{Pengujian Kecepatan 50 km/jam}

Pada pengujian kecepatan $50 \mathrm{~km} / \mathrm{jam}$ didapatkan grafik seperti pada Gambar 7 . Gambar 7 memperlihatkan bahwa kecepatan kendaraan belum dapat terdeteksi saat waktu ke-1 hingga ke-232 detik. Nilai dari respon error pada rentang waktu tersebut hampir mencapai $80 \mathrm{~km} / \mathrm{jam}$. Saat memasuki waktu ke-233 fluktuasi dari nilai respon error menurun hingga waktu ke-272 detik. Selama rentang waktu ke-233 hingga ke-272 detik kecepatan kendaraan telah terdeteksi. Hal ini ditandai dengan menurunnya fluktuasi nilai dari respon error. Setelah waktu ke-272 fluktuasi nilai respon error kembali meningkat hingga waktu ke-394.

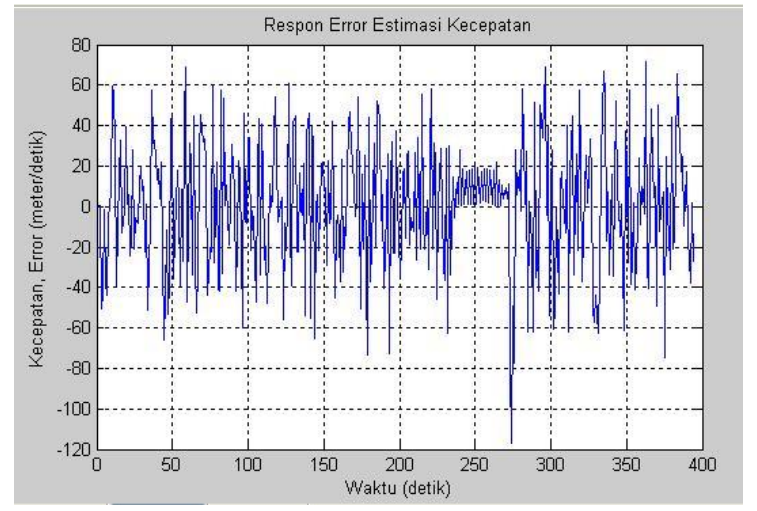

Gambar 7. Respon Error Estimasi Kecepatan $50 \mathrm{~km} / \mathrm{jam}$.
Berdasarkan hasil pengujian terlihat bahwa nilai kecepatan estimasi yang mendekati nilai kecepatan konversi adalah 13,69 m/detik. Nilai tersebut terdapat pada waktu ke-266. Apabila nilai kecepatan estimasi tersebut dikonversikan kedalam bentuk $\mathrm{km} / \mathrm{jam}$ maka kecepatan tersebut bernilai 49,28 km/jam. Nilai kecepatan estimasi ini memiliki selisih sebesar 0,72 km/jam terhadap kecepatan aktualnya.

\section{Pengujian Kecepatan 60 km/jam}

Gambar 8 memperlihatkan grafik hasil pengujian. Pada Gambar 8 terlihat kecepatan kendaraan belum dapat terdeteksi saat waktu ke-1 detik hingga ke-225 detik. Fluktuasi dari nilai respon error pada rentang waktu tersebut hampir mencapai $80 \mathrm{~km} / \mathrm{jam}$. Kecepatan kendaraan terdeteksi saat waktu ke-226 hingga waktu ke-258 detik. Hal ini ditandai dengan menurunnya fluktuasi dari nilai respon error selama rentang waktu ke-226 hingga ke-258. Saat waktu ke-259 fluktuasi nilai respon error kembali meningkat hingga waktu ke-372.

Berdasarkan hasil pengujian nilai kecepatan estimasi yang mendekati nilai kecepatan konversi adalah 16,73 $\mathrm{m} /$ detik. Nilai kecepatan estimasi tersebut terdapat pada waktu ke-254. Kecepatan estimasi yang didapat kemudian dikonversikan kembali kedalam bentuk $\mathrm{km} / \mathrm{jam}$ menjadi 60,22 $\mathrm{km} / \mathrm{jam}$. Nilai kecepatan estimasi ini terpaut selisih $0,22 \mathrm{~km} / \mathrm{jam}$ dengan kecepatan aktualnya.

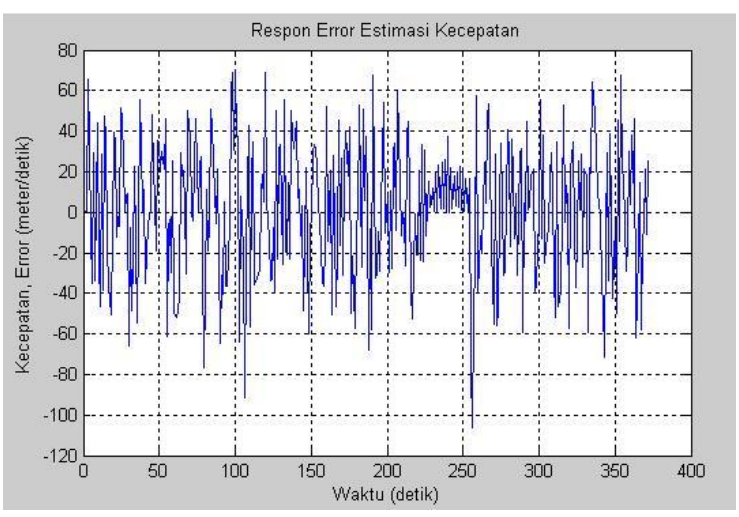

Gambar 8. Respon Error Estimasi Kecepatan $60 \mathrm{~km} / \mathrm{jam}$. 
Berdasarkan pengujian yang telah dilakukan pada masing - masing variasi nilai kecepatan di dapatkan hasil seperti pada Tabel 1.

Pada Tabel 1 terlihat antara kecepatan aktual dengan kecepatan estimasi terdapat selisih kecepatan. Selisih minimum yang terjadi adalah sebesar $0.22 \mathrm{~km} / \mathrm{jam}$ pada pengujian kecepatan $60 \mathrm{~km} / \mathrm{jam}$. Sedangkan selisih maksimum yang terjadi adalah sebesar $6.98 \mathrm{~km} / \mathrm{jam}$ pada pengujian kecepatan 5 $\mathrm{km} / \mathrm{jam}$. Perbandingan hasil kecepatan estimasi dengan kecepatan aktual tersebut jika ditampilkan kedalam bentuk grafik dapat terlihat pada gambar 8 .

Tabel 1. Hasil Estimasi Kecepatan.

\begin{tabular}{|c|c|c|c|c|}
\hline No & $\begin{array}{c}\text { Kecepatan Aktual } \\
(\mathrm{km} / \mathrm{jam})\end{array}$ & $\begin{array}{c}\text { Kecepatan Estimasi } \\
(\mathrm{km} / \mathrm{jam})\end{array}$ & $\begin{array}{c}\text { Selisih Kecepatan } \\
(\mathrm{km} / \mathrm{jam})\end{array}$ & Persentasi Error $(\%)$ \\
\hline 1 & 5 & 11,98 & 6,98 & 139,6 \\
2 & 10 & 11,81 & 1,81 & 18,1 \\
3 & 20 & 20,85 & 0,85 & 4,25 \\
4 & 30 & 30,35 & 0,35 & 1,17 \\
5 & 40 & 41,44 & 1,44 & 3,6 \\
6 & 50 & 49,28 & 0,72 & 1,44 \\
7 & 60 & 60,22 & 0,22 & 0,37 \\
\hline \multicolumn{4}{|r}{ Rata - Rata Persentasi Error } \\
\hline
\end{tabular}

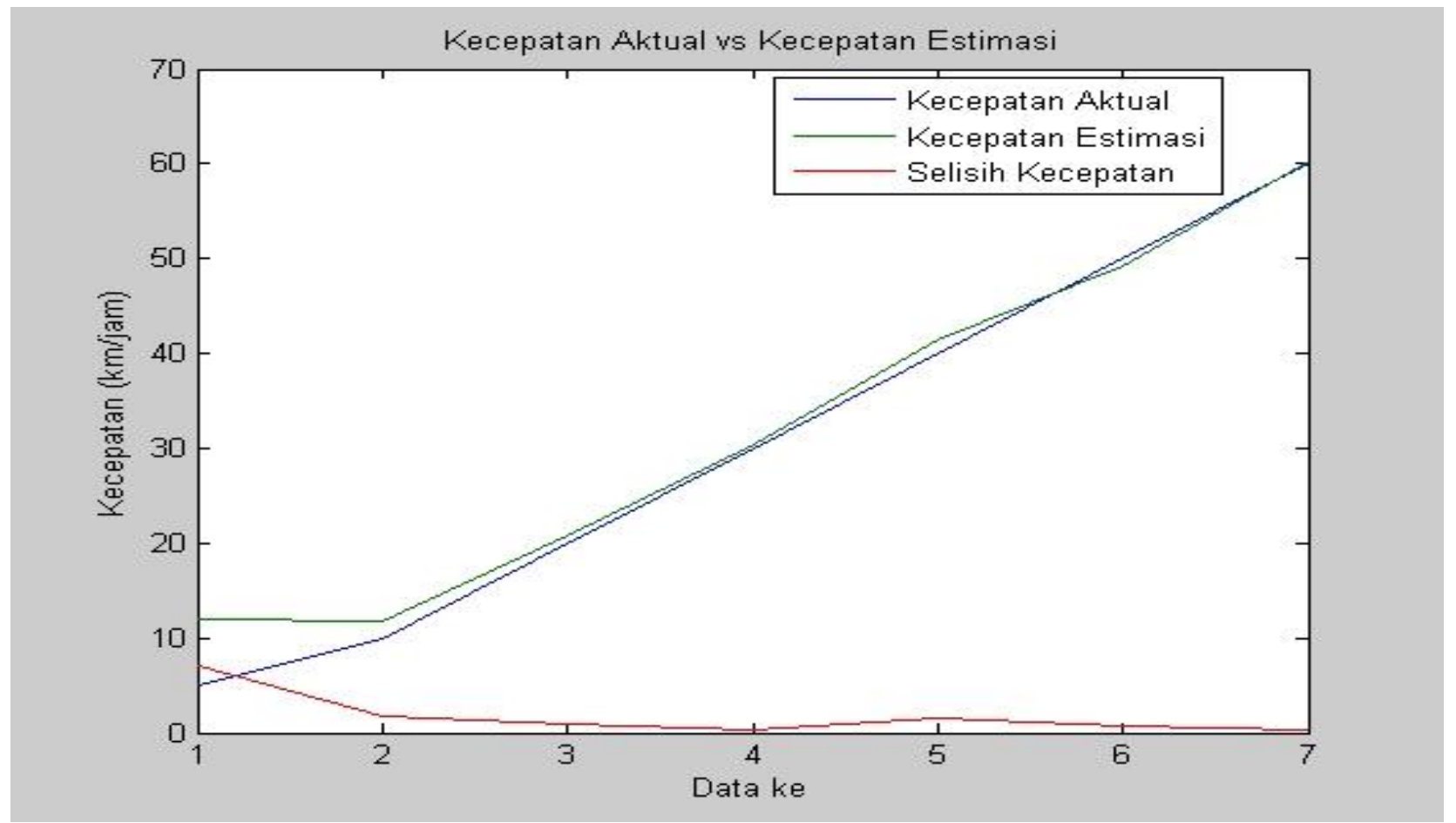

Gambar 9. Grafik Kecepatan Estimasi Terhadap Kecepatan Aktual. 
Pada Gambar 9 terlihat bahwa antara kecepatan aktual dengan kecepatan estimasi pada pengujian estimasi kecepatan $5 \mathrm{~km} / \mathrm{jam}$ terjadi selisih kecepatan yang besar. Sedangkan saat pengujian kecepatan 10 $\mathrm{km} / \mathrm{jam}$ hingga $60 \mathrm{~km} / \mathrm{jam}$ perbedaan kecepatan aktual dengan kecepatan estimasi tidak telalu jauh.

Berdasarkan hasil pada Tabel 1 terlihat bahwa saat pengujian kecepatan $5 \mathrm{~km} / \mathrm{jam}$ dan $10 \mathrm{~km} / \mathrm{jam}$ memiliki error yang terbesar. Error ini melebihi nilai toleransi error maksimal yaitu 5\%. Hal ini disebabkan pada saat perekaman video kendaraan. Pada saat perekaman video kendaraan, untuk mempertahankan kecepatan konstan tetap pada $5 \mathrm{~km} / \mathrm{jam}$ terlalu sulit. Hal ini dikarenakan speedometer yang dipergunakan kendaraan pada saat perekaman video kendaraan menggunakan speedometer analog (jarum). Sehingga untuk mempertahankan kecepatan agar akurat lebih sulit. Selain itu, tidak terdapat indikator kecepatan $5 \mathrm{~km} / \mathrm{jam}$ pada speedometer tersebut. Sehingga penentuan kecepatan 5 $\mathrm{km} / \mathrm{jam}$ hanya disesuaikan dengan perkiraan antara kecepatan 0 hingga $10 \mathrm{~km} / \mathrm{jam}$ saja. Indikator yang menunjukan kecepatan 10 $\mathrm{km} / \mathrm{jam}$ pun hanya berbentuk jarak kosong yang membagi indikator kecepatan $0 \mathrm{~km} / \mathrm{jam}$ dengan kecepatan $20 \mathrm{~km} / \mathrm{jam}$.

\section{KESIMPULAN}

Berdasarkan hasil penelitian estimasi kecepatan kendaraan menggunakan Kalman filter diperoleh kesimpulan sebagai berikut:

1. Hasil dari pengujian estimasi kecepatan didapatkan nilai estimasi untuk kecepatan $5 \mathrm{~km} / \mathrm{jam}$ adalah 11,98 $\mathrm{km} / \mathrm{jam}$ dengan error 139,6\%, kecepatan $10 \mathrm{~km} / \mathrm{jam}$ adalah $11,81 \mathrm{~km} / \mathrm{jam}$ dengan error $18,1 \%$, kecepatan $20 \mathrm{~km} / \mathrm{jam}$ adalah 20,85 $\mathrm{km} / \mathrm{jam}$ dengan error $4,25 \%$, kecepatan $30 \mathrm{~km} / \mathrm{jam}$ adalah $30,35 \mathrm{~km} / \mathrm{jam}$ dengan error $1,17 \%$, kecepatan $40 \mathrm{~km} / \mathrm{jam}$ adalah 41,44 $\mathrm{km} / \mathrm{jam}$ dengan error $3,6 \%$, kecepatan 50 $\mathrm{km} / \mathrm{jam}$ adalah 49,28 km/jam dengan error $1,44 \%$ dan kecepatan $60 \mathrm{~km} / \mathrm{jam}$ adalah 60,22 $\mathrm{km} / \mathrm{jam}$ dengan error $0,22 \%$.

2. Batas kecepatan minimal yang dapat terestimasi oleh sistem adalah sebesar 20 $\mathrm{km} / \mathrm{jam}$. Sedangkan batas kecepatan maksimal yang dapat terestimasi oleh sistem adalah sebesar $60 \mathrm{~km} / \mathrm{jam}$.

Masih terdapat kekurangan dalam penelitian ini sehingga perlu pengembangan untuk menjadi lebih baik lagi. Adapun saran dari skripsi ini untuk penelitian selanjutnya yaitu:

1. Speedometer yang digunakan dalam pengujian selanjutnya sebaiknya adalah speedometer digital agar kecepatan aktual lebih dapat akurat.

2. Metode Kalman filter dapat diterapkan untuk pengujian estimasi kecepatan pada kondisi dengan intensitas cahaya rendah atau malam.

\section{DAFTAR PUSTAKA}

Rad, G. A. R., \& Mohamadi, J. Vehicle Speed Estimation Based On The Image. SETIT $20074^{\text {th }}$ International Conference: Sciences of Electronic, Technologies of Information and Telecomunication, 2007.

Kasiyanto, I. Simulasi Penapisan Kalman Dengan KendalaPersamaan

Keadaan Pada Kasus Penelusuran Posisi Kendaraan (Vehicle Tracking Problem). Semarang: Universitas Diponegoro, 2008.

Wiryadinata, R., T.S. Widodo, W. Widada, Sunarno, S, Kliwati. Integration of GPS-INS with Kalman Filter for Rocket Navigation. ICICI-BME. Bandung, Indonesia, 2011.

Simon, D. Kalman Filtering. Embedded Systems Programming, 2001.

Republik Indonesia. PP No.79 Tahun 2013 Tentang Jaringan Lalu Lintas dan Angkutan Jalan. Jakarta: Kementrian Sekretariat Negara Republik Indonesia, 2013.

Kleinbauer, R. Kalman Filtering Implemantion with Matlab. Helsinki: Universität Stuttgart, 2004. 